\title{
Studies on Disinfection By-Products and Drinking Water
}

Drinking water is disinfected with chemicals to remove pathogens, such as Giardia and Cryptosproridium, and prevent waterborne diseases such as cholera and typhoid. During disinfection, by-products are formed at trace concentrations. Because some of these byproducts are suspected carcinogens, drinking water utilities must maintain the effectiveness of the disinfection process while minimizing the formation of byproducts.

During disinfection, the type and concentration of the disinfection byproducts formed depends on the type and amount of dissolved organic carbon present in the source water and on the chemical disinfectant used. These disinfectants include any or a combination of chlorine,

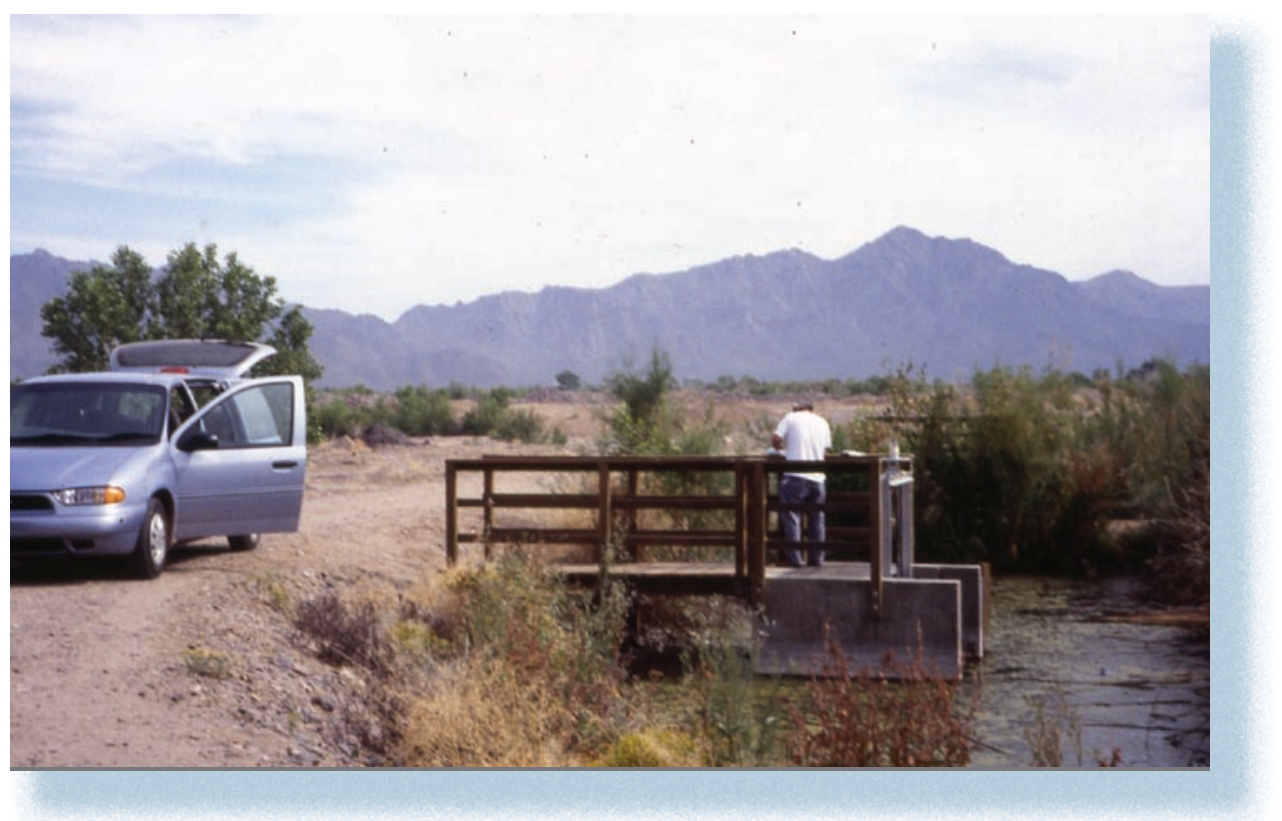

Sampling for distribution by-products in wetlands near Phoenix, Arizona. ozone, chlorine dioxide, or chloramines.

Chlorine is the most common disinfectant

in the United States, because it is effective, easy to use, and inexpensive. When chlorine is used for disinfection, it produces halogenated by-products. Specific compound classes, such as trihalomethanes and haloacetic acids, make up a majority of these halogenated by-products. Trihalomethanes have been shown to cause cancer in laboratory animals, and some haloacetic acids produce liver tumors in mice. Increased incidence of spontaneous abortions or stillbirths, or latent effects such as cancer, have been attributed to exposure to low concentrations of disinfection by-products. The fate of these disinfection by-products in the environment and ways to change the potential of source water to produce them is an important aspect of drinking-water research.

The fate of these disinfection by-products in the environment has been investigated in several studies by scientists of the U.S. Geological Survey (USGS). As water moves through wastewater treatment wetlands, most disinfection by-products are removed through volatilization, sorption, or degradation (Stricos-Martin, 1998; Keefe and others, 2004). At a constructed demonstration wetland near Phoenix, Arizona, USGS scientists found that the trihalomethanes decreased as much as 97 percent, while haloacetic acids decreased as much as 96 percent (Rostad and others, 2000a).
USGS scientists also investigated the fate of disinfection by-products during ground-water recharge. When disinfected wastewater recharges an aquifer, the disinfection by-products (volatile and nonvolatile) persist in the ground water as the recharged water moves downward and away from the source (Barber and others, 1997).

The major concern of drinking-water utilities is the potential of a source water to form disinfection byproducts. Waters from different hydrologic sources and conditions have different potentials to form disinfection by-products. Utilities have long mixed water from different sources to balance effective disinfection with the formation of disinfection by-products and the final composition of the treated water.

Determining the composition of source water and understanding the hydrologic conditions and processes that cause changes in its potential to form disinfection byproducts may help utilities produce better drinking water. USGS studies have shown that as water passes through a wetland, the amount of dissolved organic carbon increases (Barber and others, 2001), and the increase in dissolved organic carbon increases the water's formation potential for disinfection by-products (Rostad and others, 2000a). Changes in vegetation in wetlands and around reservoirs 


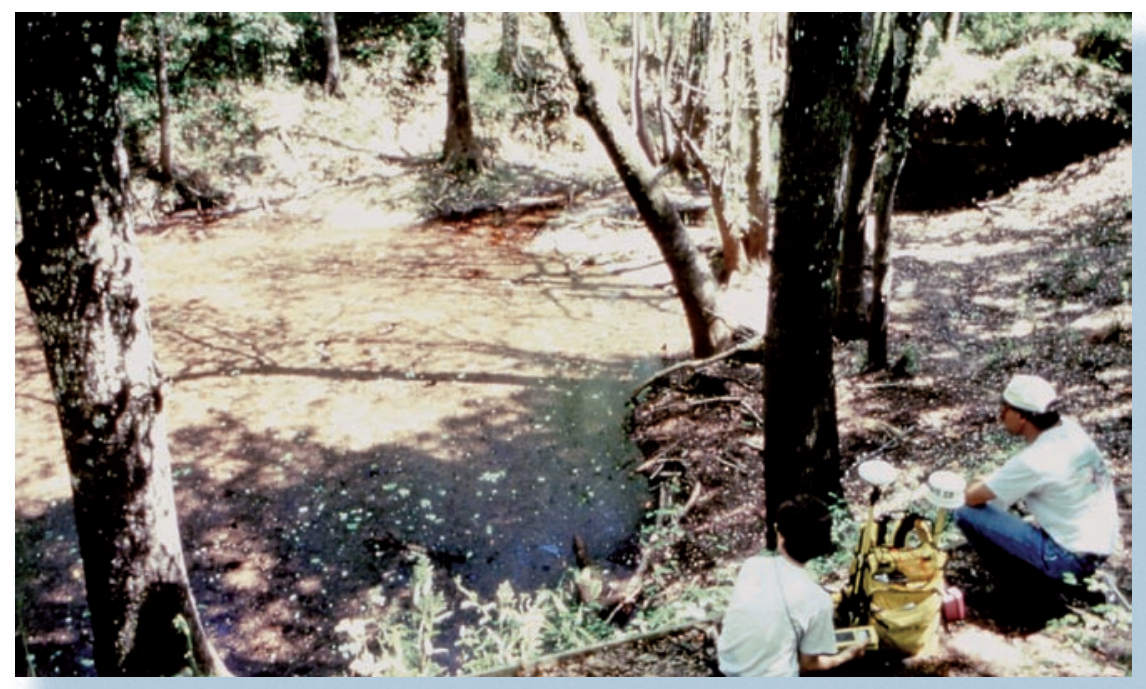

Sampling for dissolved organic carbon and disinfection by-product information potential in north central Florida

Ground water often is used as a drinking water source. Spreading basins are used in California to infiltrate reclaimed surface water into an aquifer in order to recharge ground-water resources. The quality of the reclaimed water is improved as it infiltrates downward through the aquifer material (Schroeder, 2003). USGS scientists found that the formation potential of reclaimed water did not appear to be affected much by infiltration through an aquifer during ground-water recharge (Rostad and Rathbun, 2003). However, a study

that store drinking water may help minimize inputs of organic carbon to these source waters.

Along the Mississippi River from Minneapolis to New Orleans, USGS scientists found that the dissolved organic carbon concentration decreased with distance downstream (Rathbun, 1995). The formation potentials of the surface waters to form disinfection by-products decreased also, paralleling the decrease in dissolved organic carbon. The highest dissolved organic carbon and formation potentials were found in the Upper Mississippi River. of the dissolved organic carbon showed a more complex process. Aquifer recharge removed about 60 percent of the dissolved organic carbon from the reclaimed water, but the remaining 40 percent that was partially derived from organic matter in the aquifer was more reactive in producing disinfection by-products than the 60 percent that was removed (Leenheer and others, 2001; Rostad, 2002).

A limestone aquifer in northern Florida was investigated where the surface water connects to ground water through a karstic limestone formation. Holes and tunnels

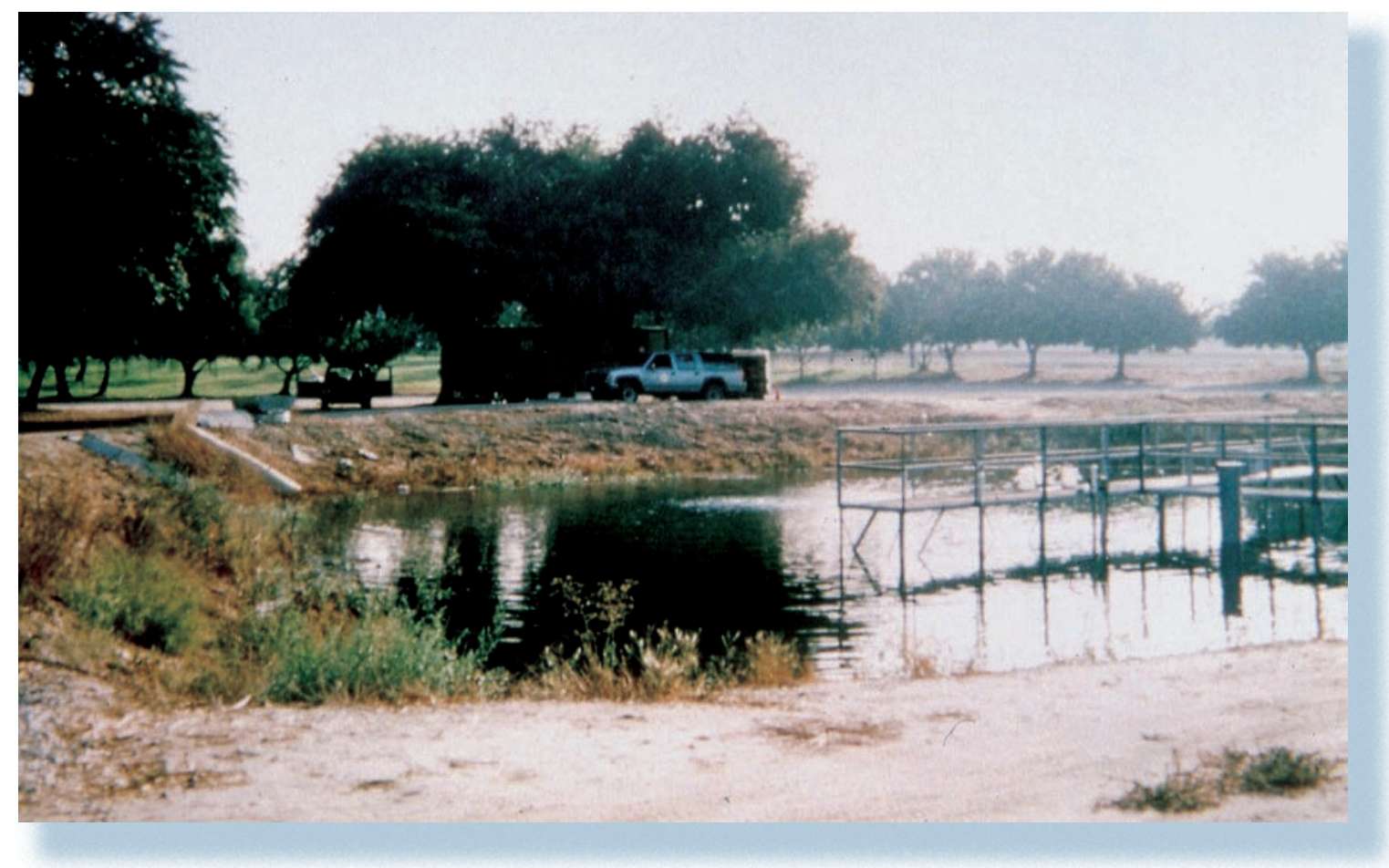

Sampling for dissolved organic carbon and disinfection by-product formation potentials at spreading basins for ground-water recharge, southern California 


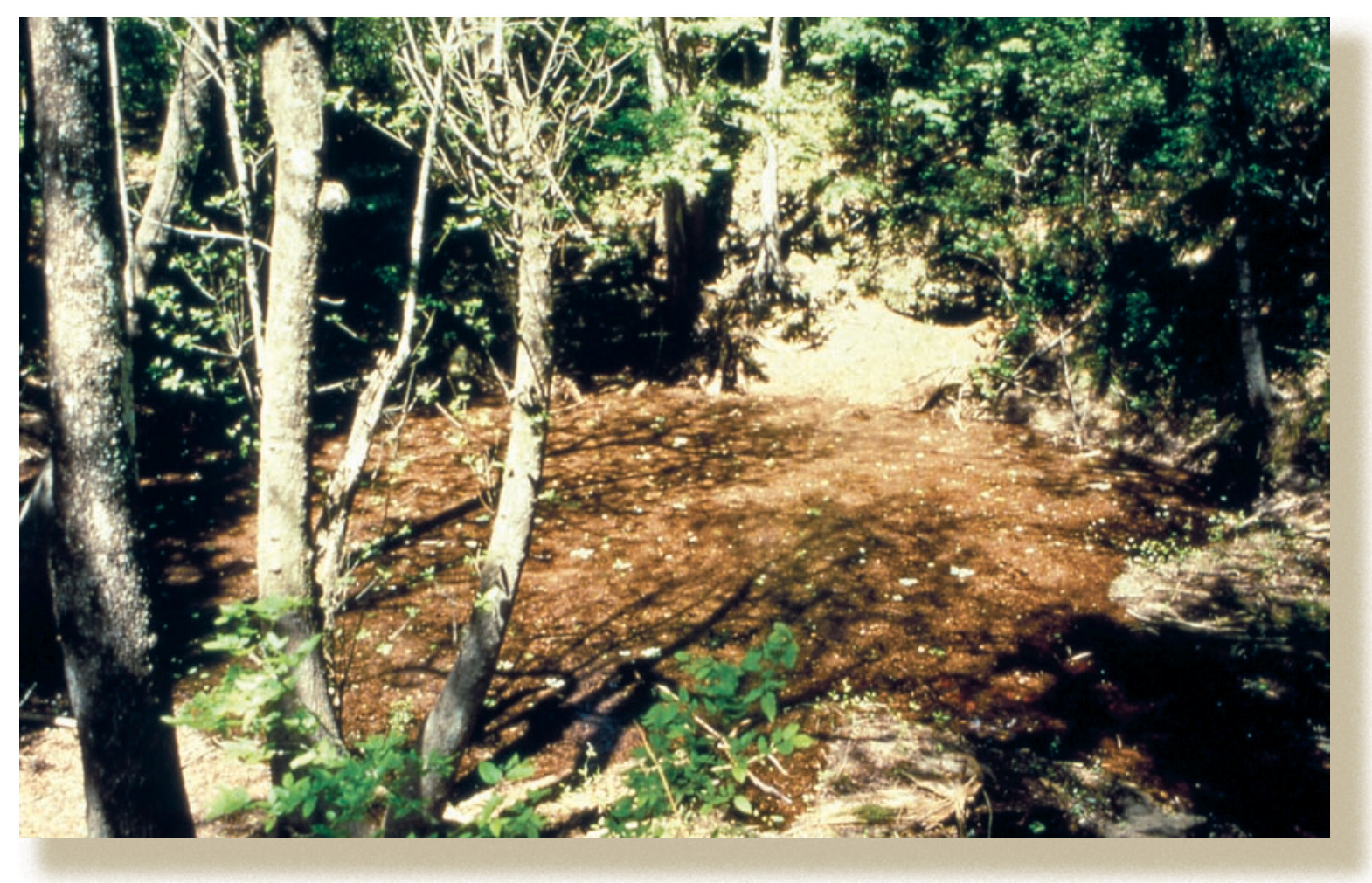

Surface water seeping into ground water through limestone karst in north central Florida

in the limestone provide direct pathways for the flow of surface water into the aquifer below. The surface-water sources are called blackwater streams because of high concentrations of dissolved organic carbon. The ground water had much lower concentrations of dissolved organic carbon than the surface water above.

The tendency to form disinfection by-products from the tannin-derived blackwater and the infiltrated ground water in the limestone aquifer in northern Florida were quite different (Rostad and others, 2000b). The dissolved organic carbon was fractionated by USGS scientists in order to determine which fractions were the most reactive in producing disinfection by-products. The drastic decrease in dissolved organic carbon during infiltration produced only minor differences in the distribution of the fractions of dissolved organic carbon, except for the colloid fraction. In this study, the colloid fraction was essentially removed during infiltration through the limestone karst.

USGS scientists found that this colloid fraction, which has large particles, was the most reactive in producing disinfection by-products. In surface waters, the colloid fraction contributes a significant portion of the dissolved organic carbon, and that portion is very reactive. The loss of this reactive colloid fraction in the ground water had the most significant effect on reducing the formation potential. Although the hydrophobic acid fraction was the most abundant fraction in the ground water, it had lower reactivity in producing disinfection by-products than other fractions. The most effective disinfection for a drinking-water utility using this ground water would involve removing the most reactive fraction of dissolved organic carbon prior to disinfection.

Studies such as these provide vital information to help drinking-water utilities understand the causes for the changes they find in the formation potential of their source waters. If certain parts of the organic matter in source waters produce more disinfection by-products than other parts, the drinking-water utilities may be able to focus their drinking-water treatment on the fraction most responsible for the formation of disinfection by-products. This will assist drinking-water utilities in minimizing the formation of disinfection by-products while maintaining effective disinfection at a reasonable cost. Additional research is needed to better understand the reactive fractions of the dissolved organic matter and to address removal of the dissolved organic carbon fractions that are not removed by present water-treatment processes. 


\section{References Cited}

Barber, L.B., Brown, G.K., Leenheer, J.A., Noyes, T.I., Rostad, C.E., and Thorn, K.A., 1997, Organic contaminants that persist during aquifer storage and recovery of reclaimed water in Los Angeles County, California: American Water Resources Association, Annual Conference and Symposium on Conjunctive Use of Water Resources, Aquifer Storage and Recovery, Long Beach, California, October 19-23, 1997, p. 261-272.

Barber, L.B., Leenheer, J.A., Noyes, T.I., Stiles, E.A., 2001, Nature and transformation of dissolved organic matter in treatment wetlands: Environmental Science and Technology, v. 35, p. 4805-4816.

Keefe, S.H., Barber, L.B., Runkel, R.L., Ryan, J.N., 2004, Fate of volatile organic compounds in constructed wastewater treatment wetlands: Environmental Science and Technology, v. 38, p. 2209-2216.

Leenheer, J.A., Rostad, C.E., Barber, L.B., Schroeder, R.A., Anders, R., Davisson, M.L., 2001, Nature and chlorine reactivity of organic constituents from reclaimed water in groundwater, Los Angeles County, California: Environmental Science and Technology, v. 35, p. 3869-3876.

Rathbun, R.E., 1995, Potentially Deleterious Effects of Chlorinating Mississippi River Water for Drinking Purposes, in Contaminants in the Mississippi River, 1987-92: U.S. Geological Survey Circular 1133, p. 136-140.

Rostad, C.E., 2002, Fate of disinfection by-products in the subsurface in Aiken, G.R. and Kuniansky, E.L. eds., U.S. Geological Survey Artificial Recharge Workshop Proceedings, Sacramento, California, April 2-4, 2002: U.S. Geological Survey Open-File Report 02-89, p. 26-29.

Rostad, C.E., Martin, B.S., Barber, L.B., Leenheer, J.A., and Daniel, S.R., 2000a, Effect of a constructed wetland on disinfection by-products, Removal processes and Production of precursors: Environmental Science and Technology, v. 34, p. 2703-2710.

Rostad, C.E., Leenheer, J.A., Katz, B.G., Martin, B.S., Noyes, T.I., 2000b, Characterization and disinfection byproduct formation potential of natural organic matter in surface and ground waters from northern Florida, 11th Chapter in the American Chemical Society Symposium Series 761, Natural Organic Matter and Disinfection Byproducts: Characterization and Control in Drinking Water, p. 154-172.

Rostad, C.E., Rathbun, R.E., 2003, Distributions of halogenated organic compounds, Chapter 11 in Schroeder, R.A., ed., Water-quality changes and organic-carbon characterization during recharge with recycled water at a research basin in Montebello Forebay, Los Angeles, California: U.S. Geological Survey Water-Resources Investigations Report 03-4146, p. 109-115.

Schroeder, R.A., ed., 2003, Water-quality changes and organic-carbon characterization during recharge with recycled water at a research basin in Montebello Forebay, Los Angeles, California: U.S. Geological Survey WaterResources Investigations Report 03-4146.

Stricos-Martin, B., 1998, Effects of wetlands on disinfection by-products and their formation potentials: Golden, Colorado School of Mines, Master of Science thesis, $109 \mathrm{p}$.

\section{Colleen E. Rostad (cerostad@usgs.gov)}

For more information, contact:

Chief Scientist, Hydrology

Branch of Hydrologic Research

U.S. Geological Survey

409 National Center

12201 Sunrise Valley Drive

Reston, VA 20192 